\title{
EGOLOGICAL ASPECTS OF AIR POLLUTION FROM AN IRON-SINTERING PLANT AT WAWA, ONTARIO
}

\author{
Alan G. Gordon \\ Research Branch, Ontario Department of Lands and Forests, Forest Biology Laboralory, Sault \\ Ste. Marie, Ontario \\ AND \\ EVILLE GORHAM ${ }^{1}$ \\ Department of Botany, University of Minnesola, Minneapolis, Minnesota \\ Received February 25, 1963
}

\begin{abstract}
At Wawa, in northern Ontario, vegetation has been damaged severely by sulphur dioxide pollution from an iron-sintering plant. Damage is mainly restricted to a narrow strip northeast from the sinter plant, since southwest winds are strongly predominant. It is traceable from the air for at least 20 miles in this direction and is estimated as severe within 11 miles and very severe within 5 miles. Within about 10 miles NE. from the sinter plant ground flora variety declines markedly, from about $20-40$ species per 40 square meter quadrat beyond this distance to $0-1$ species within 2 miles of the pollution source. At the same time sulphate in lake and pond waters increases greatly, from normal levels of about $0.2-0.3$ milliequivalents per liter to more than $0.5 \mathrm{meq} / \mathrm{l}$. within 11 miles NE. and up to $2 \mathrm{meq} / \mathrm{l}$. within 2 miles NE. from the sinter plant. Waters within about 5 miles $\mathrm{NE}$. are strongly acid ( $\mathrm{pH} 3.2-3.8$ ), but are not low in calcium. Soluble sulphate in the surface soil rises sharply within about 4 miles NE. from the pollution source, where, also, soil erosion is very pronounced, though traceable farther out.

The phanerogams most tolerant of air pollution are Polygonum cilinode and Sambucus pubens, which are infrequent in the normal forest vegetation. In quadrat stuclies along a northeast transect, seedlings of Pinus strobus were not observed within 30 miles from the sinter plant, while those of Picea glauca, $P$. mariana, and Populus tremuloides were not recorded within 15 miles.
\end{abstract}

\section{Introduction}

Studies of smelter fume pollution at Falconbridge and Sudbury, Ontario, revealed striking patterns of clamage to vegetation, correlated with sulphur fallout from smelter chimneys (Gorham and Gordon 1960a, 1960b). However, since there are three smelters in the area, and landform and land use greatly complicate vegetation patterns, the observed correlations were only approximate. At Wawa in northern Ontario, however, air pollution from a single ironsintering plant has caused extensive damage to vegetation northeast from the source, away from the strongly prevailing southwest winds, and offers a much simpler situation for investigation. This plant concentrates iron carbonate and pyrite ores and thus produces sulphur dioxide during the sintering process. Emission of this gas from the chimney stack results, as at Sudbury, in considerable damage to vegetation coming in contact with the smoke plume.

\section{Methods}

During June 7-14, 1960, sulphur fallout was investigated along a transect line from the sinter plant to 36 miles NE. of Wawa, by collecting 25 water samples from small lakes and ponds with local drainage and analyzing for

'The second author's contribution to this study formed part of his research program while he was on the staff of the Department of Botany, University of Toronto. 
sulphate, the oxidation product of sulphur dioxide. Calcium concentration and $\mathrm{pH}$ were also measured. At the same time a series of 23 quadrats was laid out along this line for floristic study, each being 20 meters long $\times 2$ meters wide (using a 20-meter chain). Quadrats were placed at random in each site, and all the macrophyte ground flora species in them listed, including tree seedlings of less than 2 inches basal diameter. Those not completely identifiable were also recorded, in order to calculate the total number of species per quadrat. Accessory species were then sought in the same habitat for about 10-20 minutes (depending on the degree of cover), and listed. Near both ends of the chain, samples of the humus layer were collected for determination of soluble sulphate, measured on a filtered extract after dried samples were shaken with 100 times their weight of distilled water for 3 hours. As at Sudbury, humus layer samples were hard to find near the pollution source, owing to severe erosion; and those collected were more or less contaminated by mineral soil, which blows and drifts freely in the eroded areas. Beyond 10 miles NE. from the sinter plant, ignition losses of normal humus layer samples ranged between 50 and $90 \%$ dry weight, while within 5 miles the range was from 20 to $70 \%$ for the most organic samples which could be found in the vicinity of the chain.

After the above studies had been completed, an aerial survey of vegetation damage was attempted in a series of helicopter flights, using the four subjective estimates of damage approximately defined in Table $\mathrm{I}$, and illustrated in Figs. 1-5. These refer to sites of normal exposure, but not to protected sites in gorges, on valley alluvia, etc., where damage is much less extensive. Toward the outer limits of cover damage the boundaries were difficult to fix exactly, since damage varied considerably with exposure, and southwestfacing slopes often showed damage farther out than did northeast-facing sites.

\section{The Plant Cover}

\section{Results}

The district surveyed is shown in Fig. $6 b$, an aerial mosaic upon which the boundaries for the four grades of damage to tree and shrub cover have been plotted, and Fig. $6 a$, which is a map showing the location of the sampling sites. It is evident from the pattern of vegetation damage that air pollution

Frgs. 1-5. Examples of the damage categories.

FIG. 1. Very severe: ground vegetation nearly all gone, just a little Polygonum cilinode remaining. Erosion evident.

FIG. 2. Severe: all overstory gone, most understory gone. Killing of understory and shrubbery intensive. Branching and low suckering only evident on Acer spicatum. Pyrus decora now nearly all dead, and Sambucus pubens although now regular, showing tip

killing. Ground vegetation now dominating, predominantly Polygonum cilinode.

FIG. 3. Considerable: overstory almost completely killed. Some white birch and white spruce still alive but dying. (Up to one-third of the trees may remain in some places.) Understory, made up predominantly of Acer spicatum, Pyrus decora (and some Sambucus pubens entering) is vigorous, as a result of release from the overstory canopy, but is much tip killed and suckering.

Fig. 4. Moderate: tip killing and crown thinning of the overstory extensive. Understory relatively little damaged, normal woodland ground flora.

FIG. 5. Not obvious: overstory with normal closed canopy. Normal understory, shrub layer, and ground flora. White spruce, balsam fir, white birch stand. 
Plate I
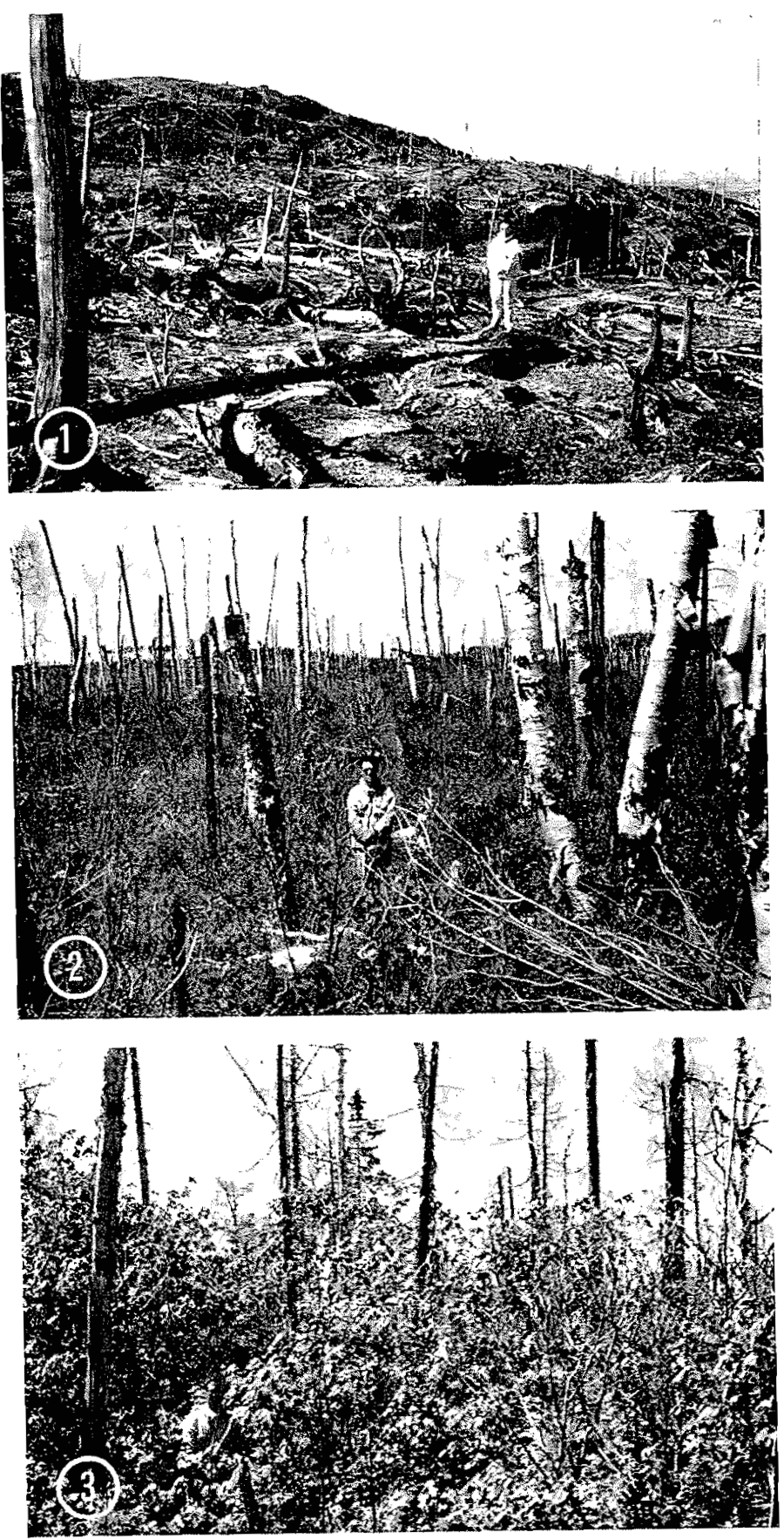

Gordon and Gorham-Can. J. Botany 
Plate II
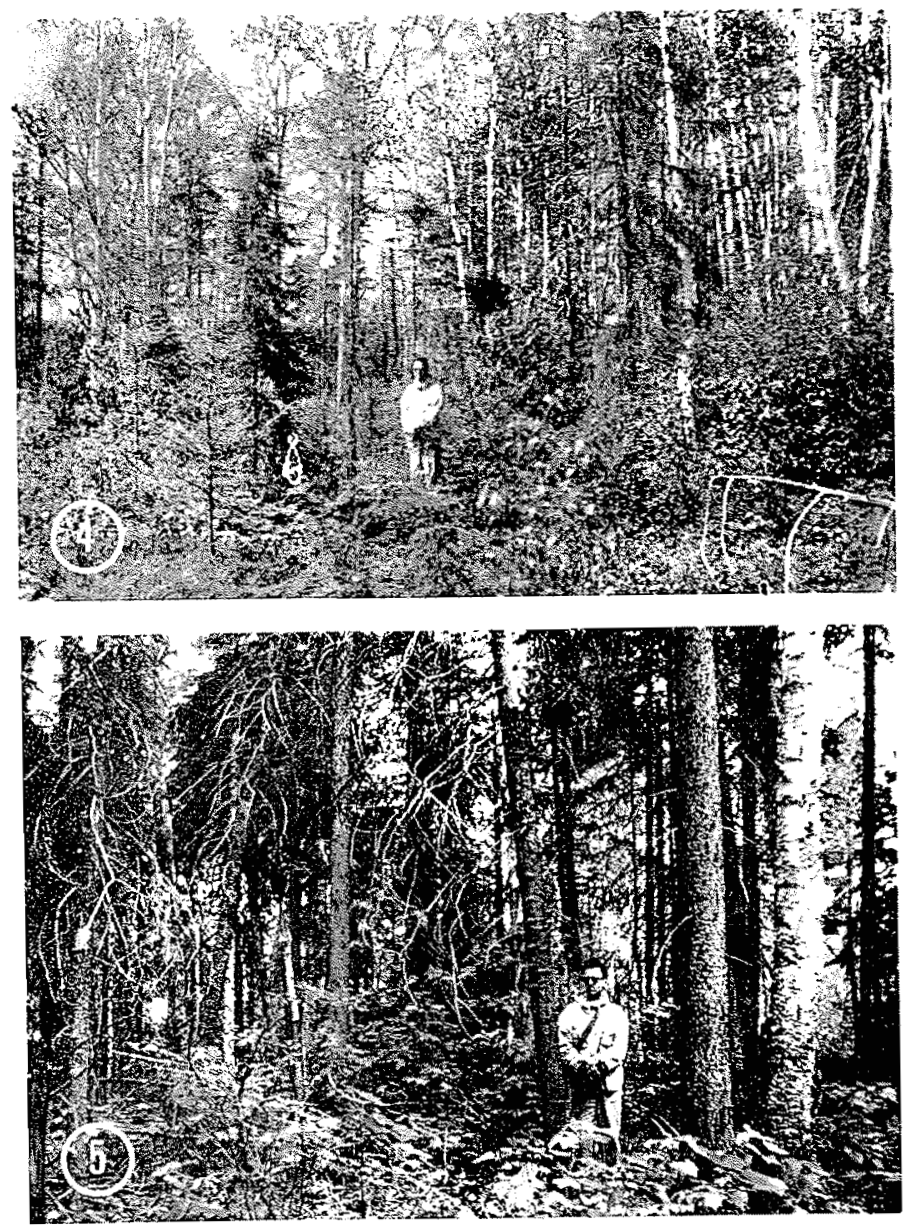

Gordon and Gorham-Can J. Botany 
TABLE I

Categories of cover damage established for aerial survey

\begin{tabular}{|c|c|c|c|c|c|}
\hline Category & $\begin{array}{c}1 \\
\text { Very' severe }\end{array}$ & $\stackrel{2}{2}$ & Considerable & $\stackrel{4}{4}$ & Not obvious \\
\hline $\begin{array}{l}\text { Overstory condition } \\
\text { and surviving tree } \\
\text { species }\end{array}$ & None & None & $\begin{array}{l}\text { Canopy mucli broken up. } \\
\text { Many dead trees beginning } \\
\text { to fall. A few white birchl } \\
\text { and white spruce remain } \\
\text { alive }\end{array}$ & $\begin{array}{l}\text { Many conifers reddened. } \\
\text { Some cllorotic. Tip kill and } \\
\text { crown thinning evident on } \\
\text { lardwoods. Surviving spe- } \\
\text { cies: *Bw, sw, Sb, A, Pj, } \\
\text { Ce, L, and Fb. (a few Pw } \\
\text { still alive) }\end{array}$ & $\begin{array}{l}\text { Overstory dominating. } \\
\text { Closed canopy: }{ }^{*} \mathrm{Bw}, \mathrm{SW}, \\
\mathrm{Ib}, \mathrm{Sb}, \mathrm{P}, \mathrm{A}, \mathrm{Ce}, \mathrm{L}, \\
\text { (Pw if present may be } \\
\text { chlorotic) }\end{array}$ \\
\hline Understory & $\begin{array}{l}\text { Almost wholly destroyed, } \\
\text { some Sambucts pubents } \\
\text { remaining alive but heav- } \\
\text { ily danaged }\end{array}$ & 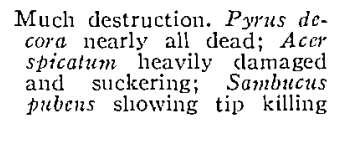 & $\begin{array}{l}\text { Understory including tall } \\
\text { slirubs dominating. Munch } \\
\text { tip killing; Pyrus decora and } \\
\text { Acer spicatum plentiful; } \\
\text { Sambuctus pubens entering } \\
\text { the understory }\end{array}$ & $\begin{array}{l}\text { Relatively little damage. Sam- } \\
\text { bucus pubens rare or absent }\end{array}$ & Normal woodland flora \\
\hline Ground vegetation & $\begin{array}{l}\text { Mostly destroyed. A little } \\
\text { Polygonum cilinodle re- } \\
\text { maining but heavily dam- } \\
\text { aged }\end{array}$ & 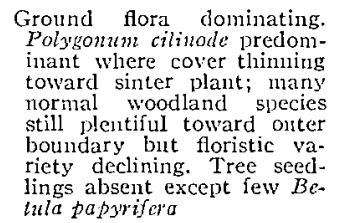 & 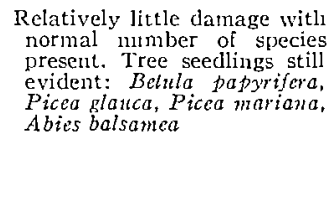 & $\begin{array}{l}\text { Normal woodland flora. Poly- } \\
\text { gontm cilinode absent }\end{array}$ & $\begin{array}{l}\text { Normal woodland flora. } \\
\text { Polygonum cilinode absent }\end{array}$ \\
\hline Erosion & $\begin{array}{l}\text { Mainly bare rock remaining } \\
\text { in exposed situations }\end{array}$ & $\begin{array}{l}\text { Evident and increasing to- } \\
\text { ward inner boundary }\end{array}$ & Not apparent & Not apparent & Not apparent \\
\hline
\end{tabular}

${ }^{*} \mathrm{Bw}$, white birch; $\mathrm{Sw}$, white spruce; $\mathrm{Sb}$, black spruce; $\mathrm{A}$, trembling aspen; $\mathrm{Pj}$, jack pine; $\mathrm{Ce}$, white cedar; $\mathrm{L}$, larch or tamarack; Fb, balsam frir; Pw, white pine. 


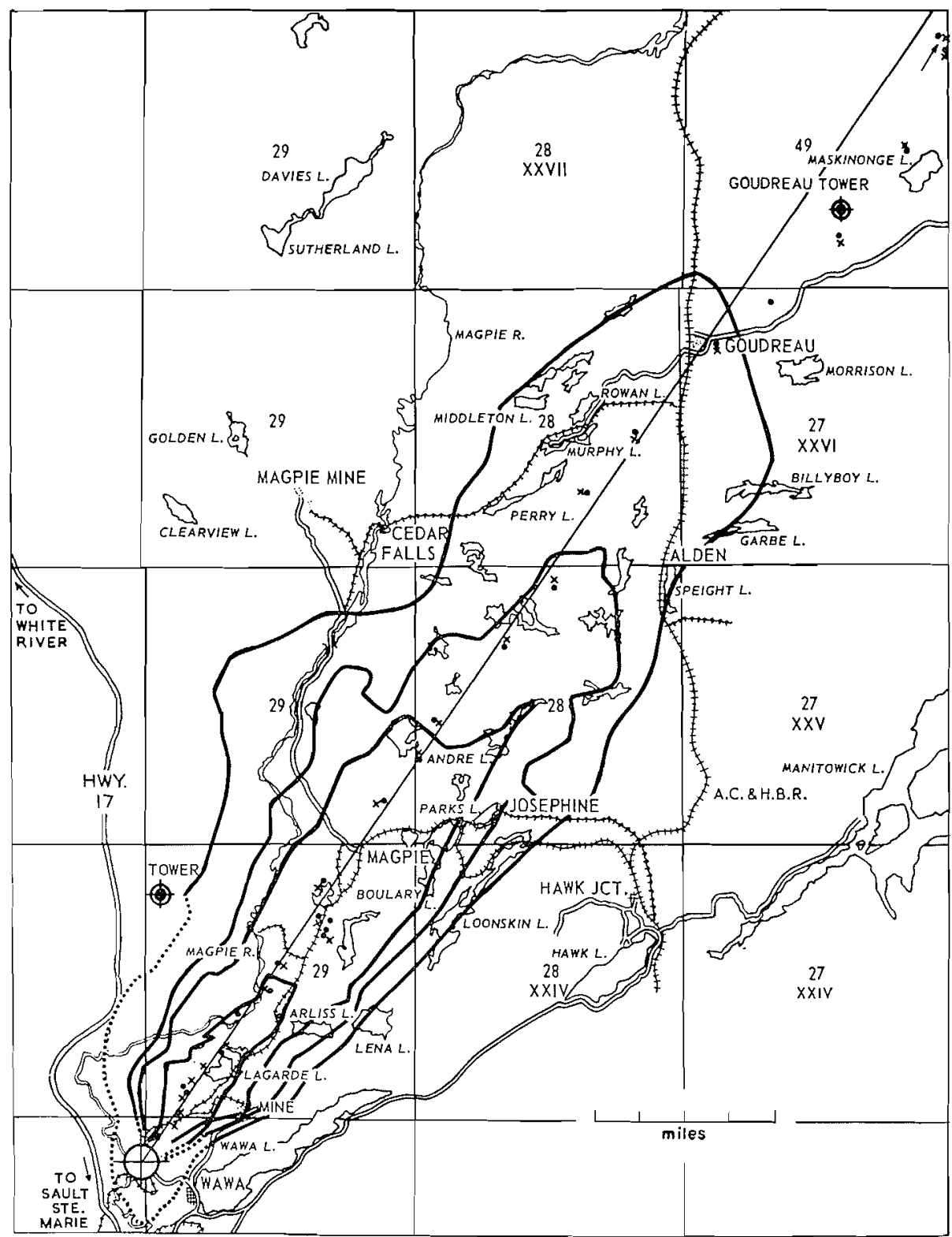

FIG. 6. (a) Map shows transect of quadrats and water samples in relation to approximate boundaries (June 1960) of cover damage as established by aerial survey. (Dots mark water samples from ponds or lakes, crosses mark sites of quadrats and humus layer samples.)

FIG. 6. (b) Aerial mosaic northeast of Wawa with boundaries for the categories of cover damage superimposed. 1 , very severe; 2 , severe; 3 , considerable; 4 , moderate; 5 , not obvious. 
Plate III

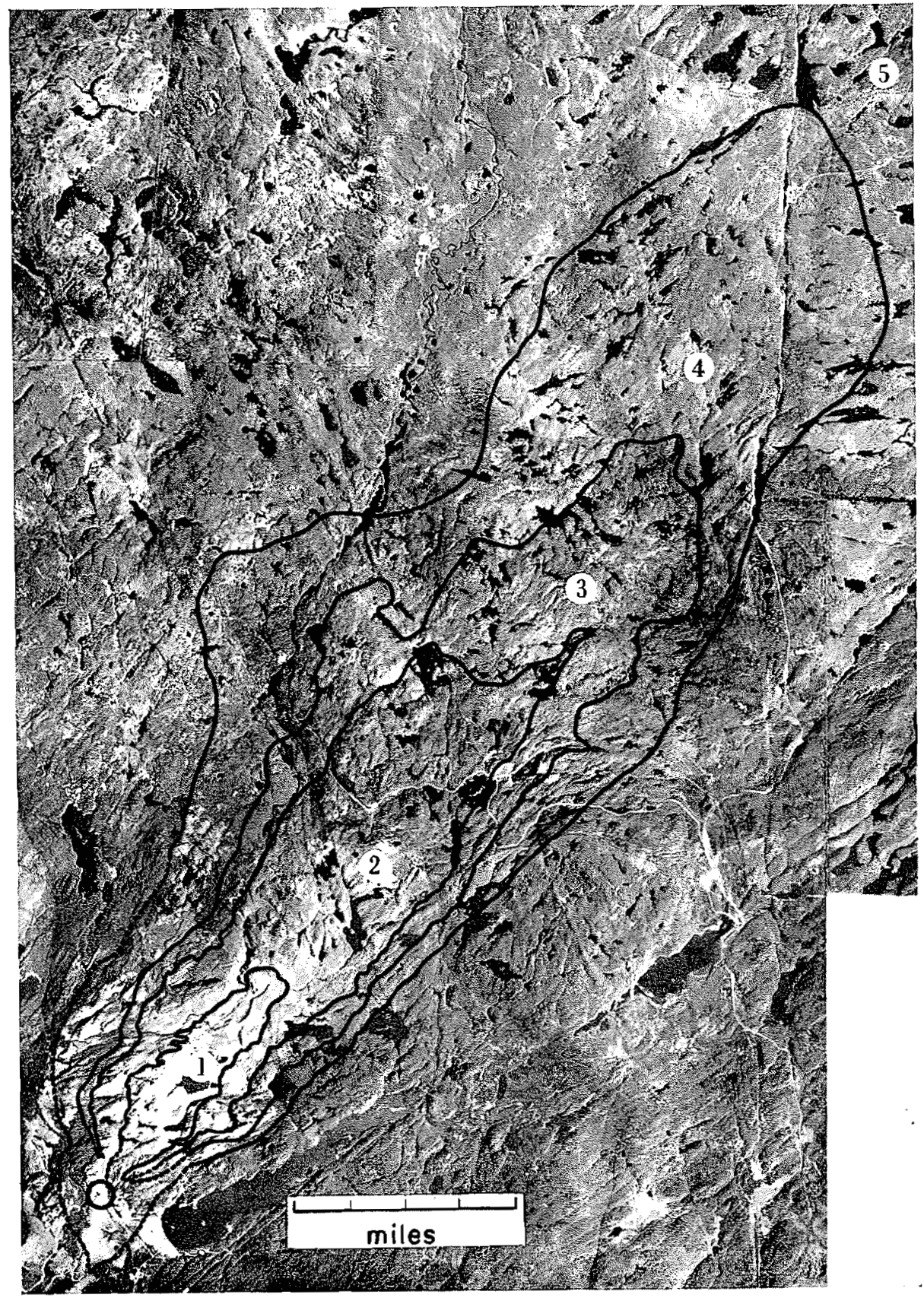

Gordon and Gorham-Can. J. Botany 
is strongly concentrated in the northeast direction, and reflects the marked predominance of southwest winds shown by the wind rose in Fig. 7. Slightly more than half of all winds from May to October of 1958 and 1959 blew from the southwest and $70 \%$ of winds above 15 m.p.h. came from this direction. (While the wind directions were only estimated to the nearest of eight compass points, the pattern of damage shown in Fig. $6 a$ suggests that the most prevalent winds actually came from between southwest and southsouthwest.)

An interesting feature of Fig. $6 b$ is the high albedo exhibited in zone 1 of "very severe" cover damage, and extending into zone 2 of "severe" damage. This is due to the destruction of the vegetation cover and extensive erosion, which has exposed much of the underlying rock close to the sinter plant. Such destruction of plant cover is clearly reflected in Table II, which reveals a striking decline in floristic variety within about 10 miles northeast from the pollution source. Figure 8 demonstrates that beyond this distance the total number of nacrophyte species recorded at each site averaged 43 , while inside 10 miles the numbers declined steadily to as few as two to four species per site within 3 miles from the sinter plant. Similarly the numbers per $20 \mathrm{~m}$. $\times$ $2 \mathrm{~m}$. quadrat declined from an average of 28 species beyond 10 miles to $0-2$ inside 3 miles.

The floristic details of pollution damage are given in Table III, where the distribution of all ground flora species identified in six or more sites northeast from Wawa is given. (One abundant moss is not included owing to failure in identification, and Streptopus roseus and amplexifolius were not separated in the field and are therefore not included.) Polygonum cilinode and Sambucus pubens, both unrecorded from the normal well-forested sites, appear to compete very successfully in strongly polluted sites where "very severe" cover

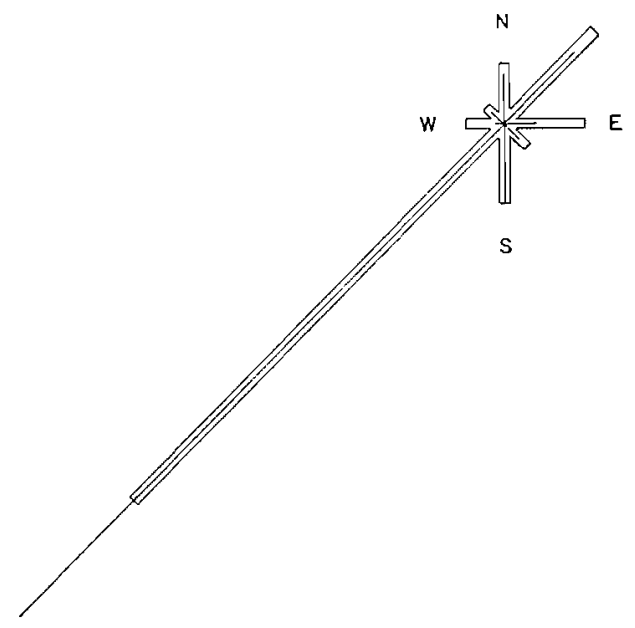

FIG. 7. Wind rose for Wawa, May to October (inclusive), 1958 and 1959. Calms made up $8 \%$ of total records. Blocks represent all winds, center lines represent winds above 15 m.p.h., which make up $10 \%$ of total records. 
TABLE II

Abundance of ground flora species and damage to vegetation, in relation to distance from sinter plant and sulphate concentration in the humus layer of the soil

\begin{tabular}{|c|c|c|c|c|}
\hline \multirow{2}{*}{$\begin{array}{l}\text { Distance NE. of } \\
\text { sinter plant } \\
\text { (miles) }\end{array}$} & \multicolumn{2}{|c|}{ No. ground flora species } & \multirow{2}{*}{$\begin{array}{c}\text { Arboreal } \\
\text { damage } \\
\text { (aerial } \\
\text { estimate) }\end{array}$} & \multirow{2}{*}{$\begin{array}{c}\text { Soluble } \\
\text { sulphate in soil } \\
\text { (meq } / 100 \mathrm{~g} \\
\text { ignition loss) }\end{array}$} \\
\hline & $\begin{array}{c}\text { (quadrat } \\
20 \mathrm{~m} . \times 2 \mathrm{~m} .)\end{array}$ & (accessory) & & \\
\hline 0.56 & 0 & 2 & VS & 31 \\
\hline 1.0 & 1 & 3 & $" s$ & 24 \\
\hline 1.2 & 1 & 2 & " & 18 \\
\hline 1.6 & 1 & 2 & " & 16 \\
\hline 2.1 & 2 & 1 & " & 15.5 \\
\hline 2.5 & 1 & 1 & $"$ & 14.2 \\
\hline 3.2 & 3 & 2 & " & 12.2 \\
\hline 4.7 & 2 & 8 & “ & 8.2 \\
\hline 5.8 & 5 & 10 & $\mathrm{~S}$ & 6.5 \\
\hline 6.4 & 9 & 6 & “ & 5.0 \\
\hline 6.6 & 15 & 5 & " & 6.9 \\
\hline 7.3 & 8 & 14 & “ & 3.9 \\
\hline 9.5 & 15 & 23 & " & 4.1 \\
\hline 10.8 & 26 & 14 & $"$ & 4.8 \\
\hline 11.7 & 20 & 16 & C & 7.6 \\
\hline 14.0 & 39 & 16 & " & 6.1 \\
\hline 15.7 & 27 & 15 & $"$ & 5.7 \\
\hline 17.3 & 32 & 17 & $\mathrm{M}$ & 4.2 \\
\hline 19.2 & 27 & 10 & $"$ & 9.2 \\
\hline 21.9 & 20 & 12 & $"$ & 9.0 \\
\hline 25.5 & 36 & 16 & $\mathrm{~N}$ & 9.4 \\
\hline 27.9 & 27 & 19 & “ & 9.1 \\
\hline 30.1 & 27 & 17 & " & 8.0 \\
\hline 36.1 & 27 & 10 & $"$ & 4.8 \\
\hline
\end{tabular}

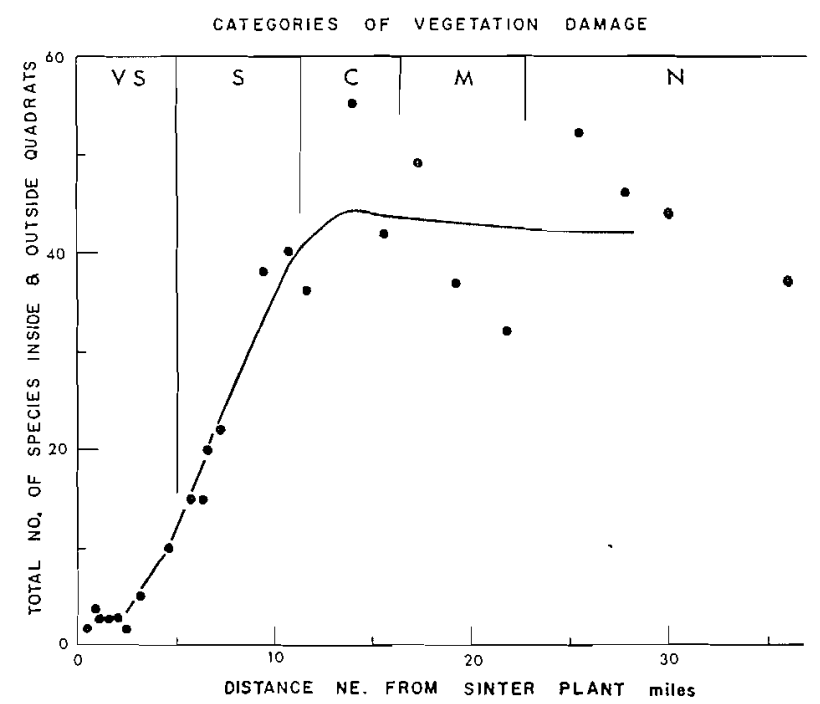

FIG. 8. The relation between floristic variety of the ground flora, aerial estimates of damage to vegetation, and distance from pollution source. (Curve fitted by running averages of five, see Table I for definitions of vegetation damage.) 
TABLE III

Distribution of the commoner ground flora species at varying distances from the sinter plant, and in relation to aerial estimates of vegetation damage Species present in 6 or (+ indicates presence in $20 \times 2 \mathrm{~m}$. quadrat, *indicates accessory species observed near quadrat. Records in parentheses indicate uncertain identi-

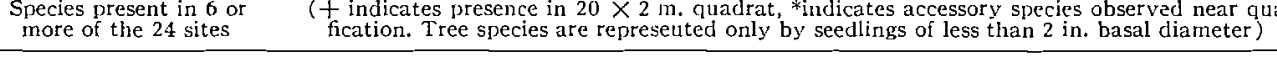

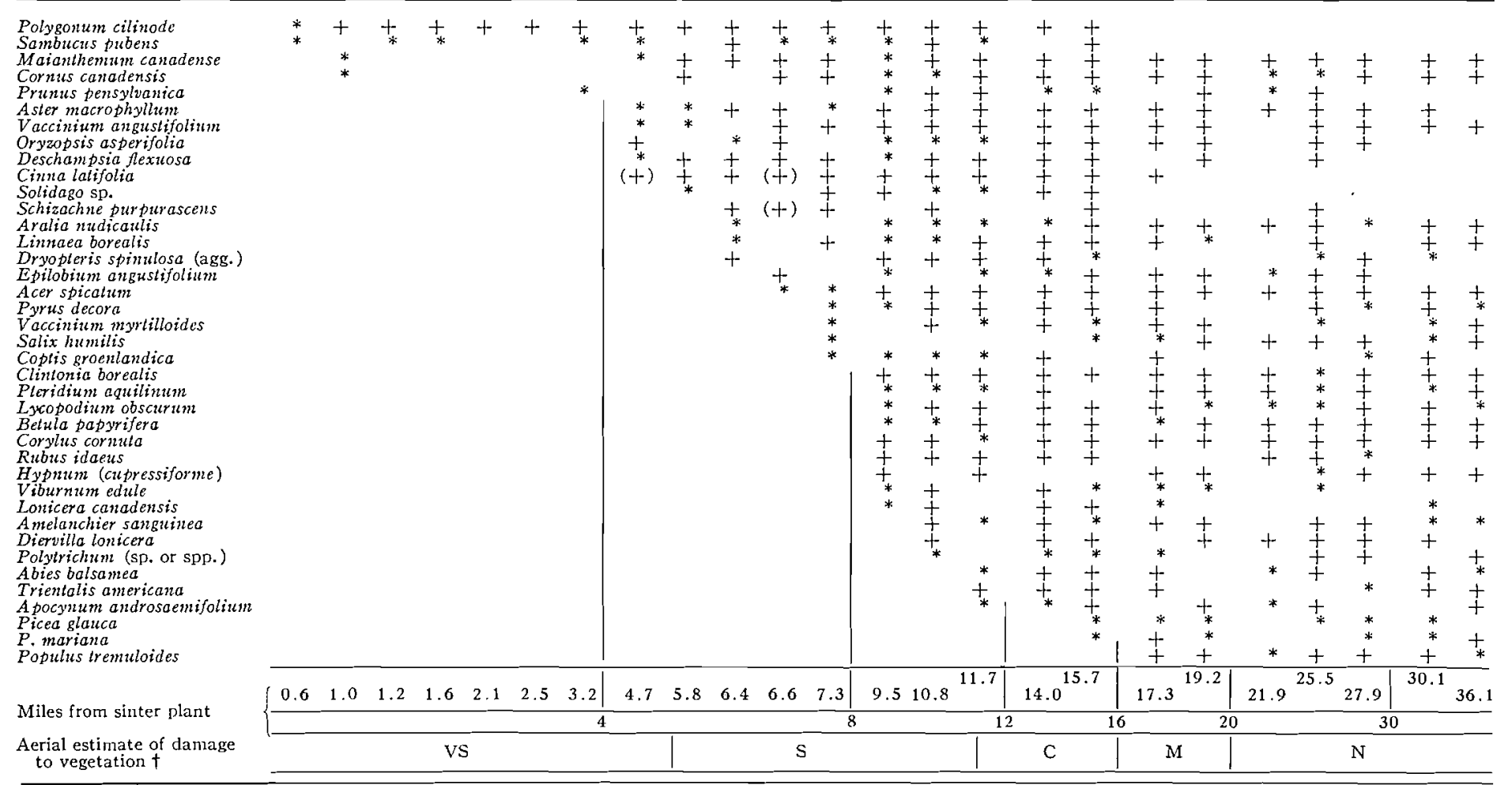

tVS, very severe; S, severe; $C$, considerable; $M$, moderate; $N$, not obvious. 
damage is observed. There, however, they usually exhibit a great deal of leaf damage, and, in Sambucus, tip killing also. A number of normal forest species extend to the inner boundary of "severe" cover damage, where all the overstory and much of the understory is destroyed. Among these are Aster macrophyllum, Vaccinium angustifolium, and Oryzopsis asperifolia. The grass Cinna latifolia is also frequent in this zone and in less damaged areas, where the cover is open, but was not recorded under the normal forest shacle. One characteristic forest species, Trientalis americana, was not observed within the boundary of "considerable" cover damage. Only five sites were examined where damage to the plant cover was "not obvious" from the air. In four of these, but not in any of the damaged sites, the common forest moss Calliergonella (Hypnum) schreberi was recorded.

Among the tree seedlings those of Betula papyrifera occurred in all sites beyond 9 miles NE. from the sinter plant, the next nearest tree seedlings being those of Abies balsamea beyond 11 miles. Seedlings of Picca glauca and $P$. mariana were common outside 15 miles, while those of Populus tremuloides were observed in all seven sites beyond 17 miles. Pinus strobus seedlings were only observed in the site 30.1 miles from the sinter plant.

\section{Chemical Properties of the Environment}

Two methods were used to trace sulphur fallout from the sinter plant. In one case estimates of soluble sulphate in the surface humus layer of the soil were made (Table II), and are shown in Fig. 9 as meq/100 g ignition loss, being thus expressed per unit of humus rather than per unit dry weight (cf. Gorham and Gordon 1960a). Concentrations ranged between about 4 and

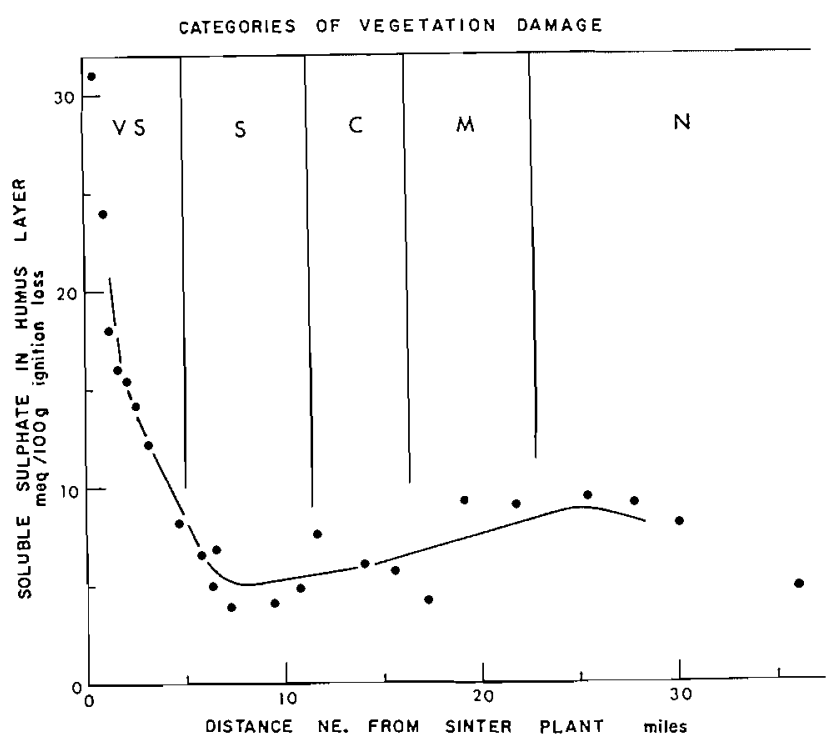

FIG. 9. The relation between soluble sulphate in the humus layer, aerial estimates of vegetation damage, and distance from pollution source. (Curve fitted by running averages of five.) 
$10 \mathrm{meq} / 100 \mathrm{~g}$ ignition loss outside 4 miles $\mathrm{NE}$. from the pollution source, with a tendency toward high values at between 20 and 30 miles. This tendency would be accentuated on the dry weight basis, and remains unexplained. However, the chief feature of Fig. 9 is a striking rise of soluble sulphate in the surface soils within 4 miles from the sinter plant, the concentration reaching $31 \mathrm{meq} / 100 \mathrm{~g}$ ignition loss at the site 0.6 miles from the source of sulphur dioxide emission. This rise in soluble sulphate occurred in the area where cover daniage was rated "very severe", and, because of erosion, samples of the humus layer were difficult to find.

The second estimate of sulphur fallout was made by measuring sulphate concentrations in the waters of small lakes and ponds with very local drainage (Table IV). As at Falconbridge, the influence of air pollution reached much farther from the source in the case of the lake waters than in that of the soils (cf. Gorham and Gordon 1960a). Indeed, in the present instance it is not certain whether the natural level of sulphate has been reached at 30 miles NE. from the sinter plant, as may be seen in Fig. 10. The correlation coefficient ( $r$ ) for logarithms of sulphate concentrations and clistances at the 25 sites is -0.96 , and the regression equation of sulphate $(y$, as meq/l.) upon distance northeast from the pollution source $\left(x\right.$, in miles) is $y=4.17 x^{-0.86: 1}$, with the standard error of the estimate $\pm 0.13 \mathrm{meq} / \mathrm{l}$. This regression still shows a distinct decline in sulphate concentration toward the outer limit of the present records at about 36 miles. However, a marked rise in lake and pond water

TABLE IV

Chemical properties of pond and lake waters in relation to distance from sinter plant, and to aerial estimates of damage to vegetation

\begin{tabular}{|c|c|c|c|c|}
\hline $\begin{array}{l}\text { Distance NE. of } \\
\text { sinter plant } \\
\text { (miles) }\end{array}$ & $\begin{array}{c}\text { Damage to arboreal } \\
\text { vegetation } \\
\text { (aerial estimate) }\end{array}$ & $\begin{array}{l}\text { Sulphate } \\
\text { (meg/l.) }\end{array}$ & $\begin{array}{l}\mathrm{pH} \text { (unaerated, } \\
\text { by glass } \\
\text { electrode) }\end{array}$ & $\begin{array}{l}\text { Calcium } \\
(\mathrm{meq} / \mathrm{l})\end{array}$ \\
\hline 1.8 & $\mathrm{VS}$ & 2.00 & 3.19 & 0.70 \\
\hline 1.8 & $" 6$ & 1.88 & 3.48 & 0.76 \\
\hline 2.9 & $"$ & 1.92 & 3.43 & 0.85 \\
\hline 4.0 & " & 0.90 & 3.18 & 0.07 \\
\hline 4.4 & " & 1.18 & 3.80 & 0.77 \\
\hline 4.7 & " & 0.96 & 3.42 & 0.62 \\
\hline 5.3 & $S$ & 1.75 & 3.63 & 1.18 \\
\hline 6.4 & "6 & 0.90 & 4.90 & 0.85 \\
\hline 6.5 & $"$ & 0.93 & 6.3 & 1.00 \\
\hline 6.7 & " & 0.97 & 6.5 & 1.05 \\
\hline 6.8 & " & 1.06 & 6.7 & 1.23 \\
\hline 7.4 & “ & 0.80 & 6.1 & 0.77 \\
\hline 9.5 & " & 0.75 & 6.7 & 1.08 \\
\hline 10.7 & 16 & 0.66 & 7.3 & 1.39 \\
\hline 11.7 & C & 0.40 & 5.6 & 0.35 \\
\hline 14.0 & 4 & 0.39 & 6.3 & 0.60 \\
\hline 15.6 & “ & 0.37 & 6.6 & 0.56 \\
\hline 17.4 & $\mathrm{M}$ & 0.25 & 6.3 & 0.43 \\
\hline 19.3 & $" 6$ & 0.25 & 6.5 & 0.42 \\
\hline 22.0 & " & 0.33 & 6.6 & 0.57 \\
\hline 23.4 & $\mathrm{~N}$ & 0.28 & 4.2 & 0.22 \\
\hline 25.5 & $"$ & 0.21 & 6.5 & 0.42 \\
\hline 27.9 & " & 0.26 & 6.4 & 0.38 \\
\hline 30.2 & " & 0.24 & 6.5 & 0.44 \\
\hline 35.9 & “ & 0.16 & 4.6 & 0.09 \\
\hline
\end{tabular}




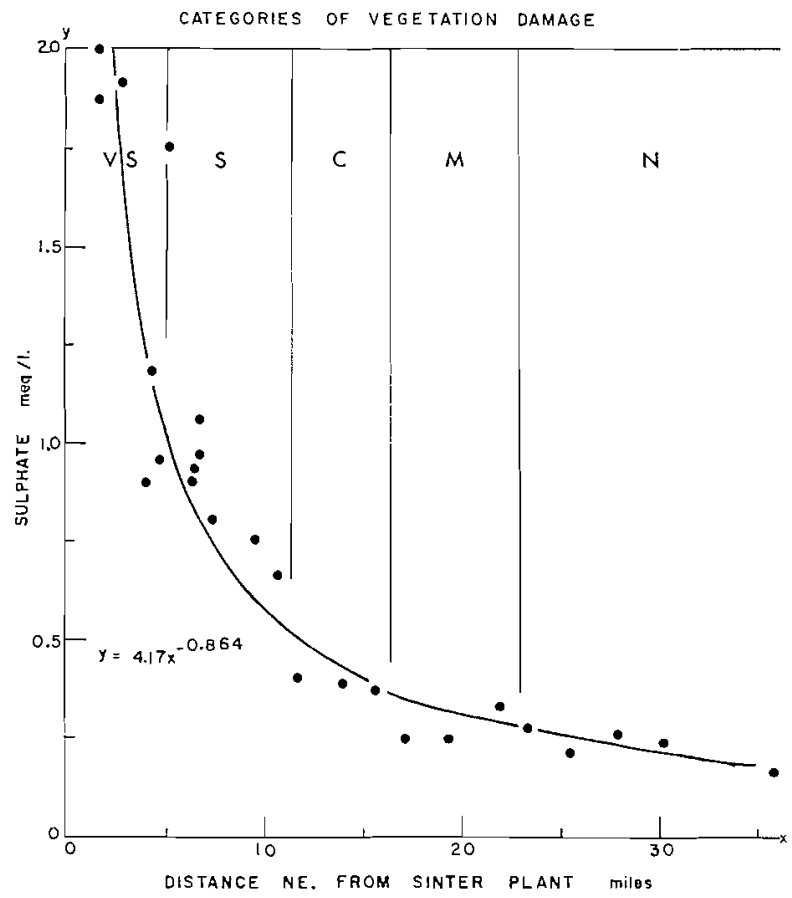

FIG. 10. The relation between sulphate in lake and pond waters, aerial estimates of vegetation damage, and distance from pollution source.

sulphate only occurred within the boundary of "severe" cover damage, at about 11 miles NE. from the sinter plant. Here concentrations were well above $0.5 \mathrm{meq} / \mathrm{l}$., while beyond 11 miles the values were below $0.5 \mathrm{meq} / \mathrm{l}$., and declined to roughly half this level where cover damage was "not obvious". The two sites nearest the sinter plant, which are in the zone of "very severe" cover damage but still 1.8 miles $\mathrm{NE}$. of the pollution source, reached concentrations of 1.9 and $2.0 \mathrm{meq} / \mathrm{l}$.

Such high levels of sulphur pollution entail strong acidity in these waters, as illustrated in Table IV and by Fig. 11. The normal $\mathrm{pH}$ level beyond about 6-8 miles NE. from the sinter plant was clearly about 6.5 , except for three of the more boggy lakes, which exhibited characteristic $\mathrm{pH}$ values ranging from 4.2 to 5.6 (cf. Gorham 1957). Within this distance, however, $\mathrm{pH}$ fell sharply, and indeed all values recorded within 6 miles were between $\mathrm{pH} 3$ and 4 . The transition thus took place near to where "very severe" graded into "severe" cover damage.

It is interesting in this connection to examine the calcium concentrations of all these waters, which are given in Table IV and shown graphically in Fig. 12. Beyond 11 miles, where sulphate was relatively low, calcium ranged between 0.4 and $0.6 \mathrm{meq} / 1$., except for the boggy waters. There lower values were recorded, and reached a minimum of about $0.1 \mathrm{meq} / 1$. In the zone of "severe" cover damage between 5 and 11 miles distance, where sulphate 
levels increased markedly, much higher calcium concentrations were observed, ranging from about 0.8 to $1.4 \mathrm{meq} / 1$. Such an increase was presumably due to the strong weathering action of sulphuric acid upon the soils and rocks of the area, which supplied enough lime to neutralize it. Within 5 miles of the sinter plant, however, where cover damage was "very severe", calcium concentrations were again much lower, between 0.6 and 0.9 meq/1. Presumably this decline is a result of eventual exhaustion of calcium in soils and rock surfaces exposed to the extremely high concentrations of sulphuric acid recorded near the pollution source. Such exhaustion would also explain the very low $\mathrm{pH}$ values found in waters near the pollution source, where soil bases have become insufficient to neutralize the acid fallout from the sinter plant.

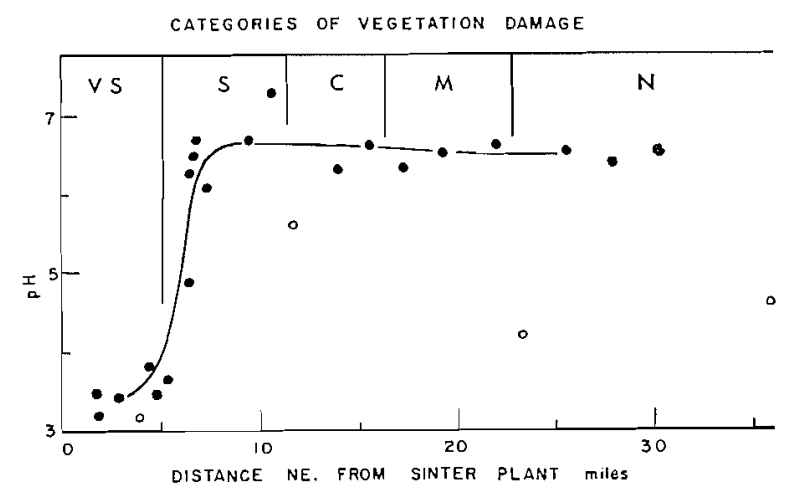

F1G. 11. Acidity in lake and pond waters at varying distances northeast from the sinter plant. (Open circles represent boggy sites not included in running averages of five used to fit curve.)

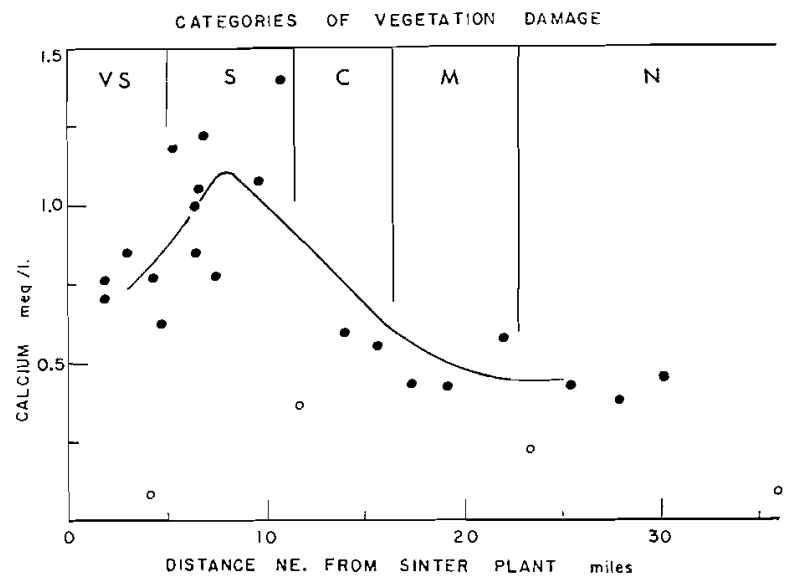

FIG. 12. Calcium in lake and pond waters at varying distances nor theast from the sinter plant. (Open circles represent boggy sites not included in running averages of five, through which freehand curve has been drawn.) 


\section{Discussion}

In examining ecological aspects of air pollution, it is of much interest to establish how far biological effects may be related to chemical indices of pollution. The present study provides instances of such relationship. Perhaps the most important is the combination of a marked decline in floristic variety (Fig. 8) with a striking rise in the sulphate concentration of lalse and pond waters at about 10-12 miles NE. from the sinter plant (Fig. 10). Here also occurred the boundary between "severe" and "considerable" clamage to the vegetation cover, as marked by complete destruction of the overstory and extensive destruction of the understory in the former case, and in the latter by the survival of a few birch and spruce among abundant understory shrubs, whose chief symptom of damage was extensive tip-killing. Similarly, the boundary between "very severe" and "severe" cover damage is approximately coincident with the rise of soluble sulphate in the humus layer of the soil as the sinter plant is approached (Fig. 9), and with the marked acidification of lake and pond waters (Fig. 11).

The outer zones of cover damage cannot be clearly demarcated by chemical properties of the environment, although there is a distinct tendency for the sulphate levels of lake and pond waters farther from the sinter plant to be lower than those nearer to the source of pollution (Fig. 10).

In order to cletermine financial loss of timber crops and other land uses under their jurisdiction, foresters of the Department of Lands and Forests, White River District, mapped the Wawa fume damaged area from the air in August 1960 and subsequently in August 1961. Three broad damage categories: "barren", "severe", and "light" were used in the mapping. This is of interest since these categories are based on damage to tree species only and are related to "total killing" of all trees, "heavy killing", and "light" damage respectively. "Light" damage is defined as early leaf fall and reduced growth. The five categories used in the present study correspond relatively well to these broad forest management categories. Hence, "very severe, severe", and most of "considerable" approximate the White River District's "barren" or "total kill", and the "moderate" category of the present study approximates White River's "heavy kill".

Since there is some seasonal variation in the damage pattern (e.g. white birch may appear undamaged early in the season and later on show considerable damage), the area of "not obvious" (Fig. 6) in the present study includes the area mapped as "light damage" by the White River District. The difference of the mapping times, early in the growing season in June, and late in the growing season in August is reflected in the permanency of the damage to tree species. The boundary between "moderate" and "not obvious" in the present study may be therefore on the conservative side since it takes only permanent damage into account. Areas of trees which may show damage late in the season would undoubtedly extend this line. Such trees, however, in the peripheral area would very likely recover and leaf out green in the following year. It should also be pointed out that occasional damage may occur to trees and other vegetation as a result of intermittent fumigations of sulphur dioxide far beyond the areas of permanent damage. It is interesting 
to note, however, that the integrated levels of the sulphate ion in lake waters show a slight but continuing decline across the area, between 23 and 28 miles from the sinter plant, which is mapped as "light" damage by the White River District.

It may also be wortliwhile to compare the results of the present study with those at Falconbridge and Sudbury (Gorham and Gordon 1960a, 1960b). In the latter area Cole (1949) reported an emission by the three smelters of about 1,000,000 tons of sulphur per year. At Wawa, emission from the sinter plant is about 100,000 tons of sulphur per year, from carrier data. While the Wawa emission is relatively small, because of the predominance of southwest winds it is strongly concentrated over a narrow strip of country northeast from the sinter plant, and so brings about vegetation damage within that strip quite comparable with the damage occurring at all points of the compass around Sudbury.

It should be pointed out here that the damage categories employed in aerial surveys at Sudbury and Wawa are not comparable in all points. For instance, at Sudbury there is a long history of pollution, while at Wawa the sinter plant operations were begun only in 1939, and much of the vegetation damage has occurred since the expansion of the plant in 1949. This relatively recent expansion of the damaged area at Wawa may account for the appearance of the vegetation, which seems to have been peeled off in layers. The tree cover, which is intact and dominating in the "not obvious" and "moderate" areas, is almost wholly destroyed in the "considerable" area, where the understory and shrub layers dominate. These, in turn, are destroyed and gone in the "severe" area, where only the ground flora remains. Finally the "very severe" area is without cover of any sort. It seems likely that, as with the tree cover, the understory and ground cover will be similarly decimated, so that damage to trees, shrubs, and ground flora will be more closely related, as appears to be the case at Sudbury. In this regard it is interesting to note that, at Sudbury, where damage conditions have stabilized, the damaged areas also appear relatively stable, while at Wawa the area delineated as "considerable" damage is apparently developing towards "severe". This agrees in part with the White River District's survey (1961) in which it is indicated that the area of "heavy kill" is developing towards "total kill". However, there is no appreciable difference in the boundaries of the inner areas mapped as "total kill" (all trees) and "heavy kill", in the consecutive White River surveys of August 1960 and August 1961. Erosion at Wawa, which is extensive only in the "very severe" area and not well marked in the "severe" area, may also be expected to increase as the cover continues to be depleted.

A detailed ground flora comparison is possible at the Wawa sinter plant and the Falconbridge smelter, for transects in the direction of the prevailing wind were examined in both sites. Table $\mathrm{V}$ compares the nearness of approach of various common species to the pollution source in both areas. While the comparison is, of course, rather crude, certain features stand out. For instance, in both places Sambucus pubens, Polygonum cilinode, and Maianthemum canadense appear distinctly tolerant of pollution, and the coniferous 
seedlings of Pinus strobus, Picea mariana, and Abies balsamea sensitive to it. The herbaceous species Trientalis americana also appears sensitive to pollution in both areas. Picea glauca seedlings, which first appeared at 15.7 miles NE. of the Wawa sinter plant, were also recorded only in the outer sites beyond 10 miles NNE. from Falconbridge.

Some species, however, appear to behave rather differently in the two areas. For example, Lonicera canadensis and Diervilla lonicera do not occur within 10 miles NE. at Wawa, but are recorded at only 0.8 miles NNE. from the Falconbridge snelter. Populus tremuloides seedlings were observed only 1 mile from the pollution source at Falconbridge, but not within 17 miles NE. from the Wawa source. In contrast, Vaccinium myrtilloides appeared to be

TABLE $V$

Pollution tolerance of ground flora ond tree seedlings common to wawo and Falconbridge and growing on similor physiographic sites

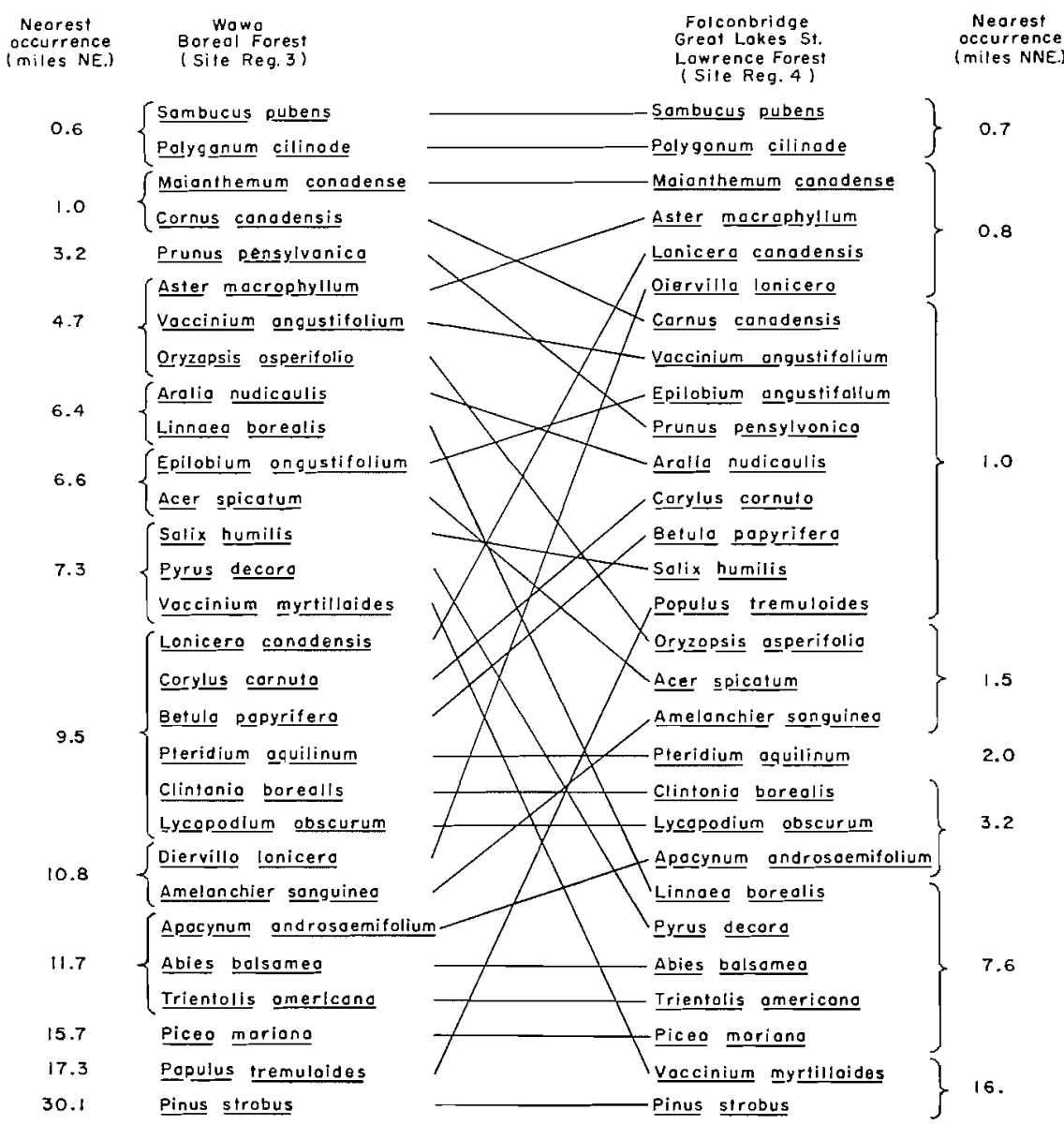


one of the most sensitive species at Falconbridge, but fell into the intermediate group at Wawa. Minor site differences influencing the distribution of these species may exist and further studies would be necessary to prove a real difference in species behavior at the two sites.

As a result of a difference in latitude between Falconbridge and Wawa and a consequent change in the vegetation from the Great Lakes St. Lawrence Forest to the Boreal Forest, Rowe (1959), or from site Region 4E at Falconbridge to site Region 3E at Wawa, Hills (1959), a number of species common at Falconbridge are absent at Wawa or at the northern limit of their range. In some cases a species common in the more southern area will be replaced by another species of the same genus in the boreal area. Such is the case with the genus Acer. At Falconbridge the temperate Acer rubrum is ubiquitous and very tolerant of smelter fume pollution. Acer saccharum is less common but quite fume tolerant. Acer spicatum, a casual species at Falconbridge, is also quite fume tolerant. At Wawa Acer saccharum is absent, and Acer rubrum, at its northern limit, does not occur frequently enough to obtain a measure of its fume tolerance. Acer spicatum however, a shade tolerant, boreal species replaces $A$ cer rubrum as one of the last arboreal species to succumb to smelter fumes. Pinus strobus, although only a scattered tree and at its northern limit north of Wawa, acts in much the same way there as at Falconbridge. While no Pinus strobus seedlings were observed either on or off the quadrats less than 30.1 miles NE. of Wawa, a very few of the scattered trees in the overstory remained alive as close as 15.7 miles NE. along the transect from the sinter plant. At Falconbridge Pinus strobus still alive were first observed at 16 miles along the transect NNE. from the smelter. In both areas at this distance white pines, where they existed, were commonly chlorotic or reddened.

\section{Concluding Remarks}

At both Wawa and Sudbury, a great many similarities exist in the pattern of pollution effects upon both environment and vegetation. However, while in both areas the populations live in close proximity to the sources of pollution, at Wawa the fortunately strong predominance of southwest winds allows the town to escape severe sulphur dioxide fumigations far more often than is the case at Sudbury. This difference, together with the fact that at Wawa a relatively small emission causes quite strong local biological damage owing to its concentration in one quarter of the compass, serves to emphasize further the desirability of preliminary ecological investigation before industrial operations of such a kind and magnitude are undertaken.

\section{Acknowledgments}

We are most grateful to $\mathrm{Mr}$. Keith Acheson, Regional Director of the Ontario Department of Lands and Forests at Sudbury, for allowing the use of a helicopter, and to the pilot, Mr. Henry Gates, for his helpful co-operation. The weather records for Wawa were kindly supplied by Mr. Aubrey Dumne, District Forester of the Department of Lands and Forests, White River District, and we are indebted to Mr. Calvin MacDonald, Chief Ranger of the Wawa Division for allowing us the use of a vehicle and for other courtesies. 
We are also indebted to the Biographic Unit of the Canada Department of Agriculture for art work on the map, to the Photographic Unit, Forest Resources Inventory, Ontario Departnent of Lands and Forests for the aerial mosaic, and to Mr. D. C. Anderson and his staff of the Forest Insect Laboratory for photographic reproduction of the plates and figures. We are also grateful to Dr. J. H. Soper of the Botany Department, University of Toronto, for identifying or checking a number of our plant specimens. The Advisory Committee on Scientific Research, University of Toronto, provided funds for some of the apparatus used in this study.

\section{References}

Cole, R. J. 1949. The removal of sulphur gases from smelter fumes, 1947. A report by the Ontario Research Foundation. The King's Printer, Toronto.

Gorham, E. 1957. The chemical composition of lake waters in Halifax County, Nova Scotia. Limnol. Oceanog. 2, 12-21.

GorhaM, E. and Gordon, A. G. 1960a. Some effects of smelter pollution northeast of Falconbridge, Ontario. Can. J. Botany, 38, 307-312.

$1960 b$. The influence of smelter fumes upon the chemical composition of lake waters near Sudbury, Ontario, and upon the surrounding vegetation. Can. J. Botany, 38, $477-487$.

HiLls, G. A. 1959. A ready reference to the description of the land of Ontario and its productivity. Ontario Dept. Lands and Forests, Research Branch, Maple, Ontario.

Ontario Department of Lands and Forests, White River and Sault Ste. Marie Districts. 1961. Unpublished map accompanying Report to the Advisory Committee to the Minister, Sept. 1961. Mimeo., limited distribution.

Rowe, J. S. 1959. Forest regions of Canada. Can. Dept. Northern Affairs Natl. Resources, Forestry Branch, Ottawa, Bull. No. 123. 